\title{
Dynamizing Innovation Systems through Induced Innovation Networks: A Conceptual Framework and the Case of the Oil Industry in Brazil
}

\author{
Ivan Pellegrin', Moisés Villamil Balestro², José Antônio Valle Júnior³, Sérgio Luiz Vaz Dias
}

\begin{abstract}
Based on the evolution of National, Regional, Sectoral and Technological Innovation Systems concepts, a conceptual framework is proposed to explain the configuration and coordination of innovation networks through an induction process. The networks may better cope with the growing complexity in innovation processes by promoting a more finetuning articulation between the innovation systems' elements. The Induced Innovation Network suggested by the article is particularly relevant in less matured Innovation Systems. The framework proposed is illustrated with the case of the PETRO-RS Network, a multi-sectoral innovation network located in the South of Brazil.
\end{abstract}

Key words: innovation networks; innovation systems; coordination; policy; supply chain; oil and gas industry.

\footnotetext{
I Produttare, Porto Alegre, Brazil. Rua Engenheiro Afonso Cavalcanti, 54 - Bela Vista - Porto Alegre, RS - 90440 - I I 0. Tel. +55 (5I) 3024 5536. Email: pellegrin@produttare.com.br

2 Universidade de Brasília, Centro de Pesquisa e Pós-graduação das Américas (CEPPAC) - Campus Darcy Ribeiro - Multiuso II, I piso. Brasília - Distrito Federal CEP 70910-900, Brasil. Tel. +55-6I- 3107-5803. Email: moises@unb.br

3 Universidade do Vale do Rio dos Sinos (UNISINOS), São Leopoldo, Brazil. Programa de Pós-graduação em Administração da UNISINOS Av. Unisinos, 950 - B. Cristo Rei / CEP 93.022-000 - São Leopoldo (RS). Tel. +55 (5I) 359 I I I 22.

Email: junico@produttare.com.br

${ }^{4}$ Universidade do Vale do Rio dos Sinos, São Leopoldo, Brazil. Departamento de Administração da UNISINOS Av. Unisinos, 950 - B.

Cristo Rei / CEP 93.022-000 - São Leopoldo (RS). Tel. +55 (5I) 359। I I22. Email: slvdias@terra.com.br
} 


\section{Introduction}

As technological development and globalization grow more important, firms' internal needs to absorb and apply new knowledge increase. In parallel, the resources external to the firm that may help its innovation processes increase in the same proportion. Such resources include financial resources to the development of new products and processes; technological, organizational, legal and tributary knowledge; complementary production resources and lab equipment for trials and tests, among others. A number of these resources can be potentially found in the technological infrastructure of the Innovation Systems to which firms belong (National System, Regional System and Sectoral and Technological Innovation Systems). The effective appropriation of such resources by firms depends on a better coordination among the multiple actors of innovation systems. It also represents a challenge, especially for Governments and Firms from less developed countries and regions with a lower economic density and where collaboration between actors is not as developed as in mature Innovation Systems.

The technology push, a linear model that has oriented public policies in some countries like Brazil until very recently, has proved ineffective in leading the economy to international competitiveness standards, especially in sectors with a larger technological content. The transition to systemic models - where demand stands as the basic input to encourage innovation - appears to advance slowly, particularly in regions with a loosely structured Innovation System. The induction of Innovation Networks to link actors in Innovation Systems by a central coordination mechanism may help step up the competitiveness of firms embedded in these contexts, as well as accelerate the maturation of the Innovation Systems themselves.

In the case of less developed countries that, however, have a relatively mature manufacturing infrastructure, the articulation between actors of Innovation Systems motivated by complex demands from capital-intensive sectors may generate a new economic dynamics. This is occurring, for example, in the Brazilian oil industry, whose product demand from various economic sectors shows a large technological diversity. In this context, innovation processes require the articulation between elements from various dimensions of Innovation Systems (National, Regional and Sectoral). Besides the understanding of the relations between the elements of the Innovation Systems, it is necessary to improve the coordination mechanism among the various actors because it promotes systematic and qualified interactions between them, strengthening innovation processes.

To lay the grounds for this discussion, this article presents the evolution of National Innovation Systems (Freeman, 1987; Lundvall, 1992; Nelson, 1993; Edquist et al., 1998; Freeman, 2002), Regional Innovation Systems (Cooke, 1997; Cooke e Morgan, 1998; OEA, 200I, OCDE, 2001; Chung 2002; Cooke et al, 2004), Sectoral Innovation Systems (Malerba, 2002 e 2004), Technological Systems (Carlsson and Stankiewicz, 1995; Carlsson et al, 2002) and Innovation Networks (DeBresson et Amesse, 1991; Rothwell, 1996; Williamson, 1996; Powell et al., 1996; Green et al., 1999; Kumaresan et Miyazaki, 1999; Günter et Pyka, 2002; Nooteboom, 2004). Next, a conceptual framework of Induced Innovation Networks is discussed, proposing that the relations between elements of different dimensions of Innovation Systems can be coordinated by a governmentinduced network with its own coordination structure. The framework is illustrated with the case of the PETRORS Network, a multi-sectoral innovation network located in the Brazilian southern state of Rio Grande do Sul. It consists of oil supply companies, in addition to research labs, financial agents and government entities. The expectation is to take advantage of a window of opportunity that may allow Brazilian firms to increase their technological capacity. Petrobras, a Brazilian stateowned company that is a world leader in oil exploration, deep water production and heavy oil refining, plans to invest alone estimated $U \$ 60$ Billion in goods and services this decade.

The article findings point to a more proactive role on the part of government in creating coordination structures to boost Innovation Systems. In the case of developing economies, to induce the formation of regional innovation networks concentrated on the supply of goods and services to capital-intensive industrial sectors, such as the oil sector, is a promising possibility to public policy makers and signals a great potential for technological diffusion to various industries. 


\section{National Innovation System - NIS}

The theoretical construction and the first applications of the National Innovation System approach in innovation studies evidenced that nations' growth and economic development are strongly related to public policies. The following policies stand out: education, science and technology policy, industrial policy and foreign trade policy (Freeman, 1987; Porter, 1990; Lundvall, 1992; Nelson, 1993). According to these authors, the NIS maturity is a key factor in the country's economic development. Also, innovation processes are significantly impacted by firms' interactions with other actors such as: universities, research institutes, financial organizations, clients, suppliers, firms producing complementary goods and others. Basically, even though innovation itself takes place within firms, the innovation process efficiency and effectiveness depend on a set of external factors that enable both its development and diffusion. Some of these external factors, particularly those of an institutional nature, have a tendency to act over the whole set of firms in a given region or country, decisively influencing the national or regional economic performance.

Lundvall (1992) defines NIS as the elements and relationships which interact in the production, diffusion and use of new, and economically useful, knowledge, which are either located within or rooted inside the borders of a nation state. Elements are understood not only as the agents but also their interactions and the attributes motivating these interactions, a topic that will be deeper discussed later in this article.

Even though NIS studies in the beginning of the 1990s were focused on the maturity of National Innovation Systems and their impact on technological innovation processes, empirical evidences already stressed the importance of other types of innovation. Organizational innovation, for instance, deals with issues concerned with the implementation of advanced management techniques as well as changes in organizational structures, the implementation of new corporative strategic orientations, marketing strategies and knowledge management which would also dramatically impact companies' performance (Lall, 1992; Freeman, 1995).

The knowledge management importance is also revealed in the first conclusions of the studies conducted by the NIS
Project, started by the OCDE in 1994 (David and Forey, 1995). Those pointed out that policy-makers should be better acquainted with the performance of theirs and other nations concerning knowledge distribution. They should be able to evaluate the magnitude of potential losses in innovations as a result of limitations in knowledge distribution and knowledge-pooling capabilities in the country, in order to define policies and actions to overcome those constraints (David and Forey, 1995).

Firms' capability of exchanging knowledge with other agents emerges as having as much importance as the capabilities directly applied in the R\&D projects. According to Freeman (1995, p. II) “...not only were inter-firm relationships shown to be critical importance, but the external linkages within the narrower professional sciencetechnology system were also shown to be decisive for innovative success...".

Along with the recognition given to interactions between actors, other types of innovation become relevant. Edquist et al. (1998) stress the importance of institutional innovations. While organizational innovations concern actors interacting in the system, institutional innovations have to do with "the rules of the game or structural conditions" (Edquist et al., 1998; p. 04) that establish the interactions between these actors. They are attributes that motivate those interactions and can be classified into three main groups (Geels, 2004): (i) cognitive informal (priorities, beliefs, culture); (ii) normative informal (norms, values, authority systems, conduct codes); and (iii) regulation formal (laws, formal rules, sanctions, regulations, contracts, technical norms, among others). Innovations of a formal regulation nature are possibly those that most affect a nation's firms, reinforcing the brokering role of policymakers concerning the making of public policies in tune with more effective innovation processes.

Part of these interactions takes place at a global level, especially in the case of large transnational firms. This becomes stronger in a globalized economy. In this context, it will be relevant to analyze innovation systems levels other than the national one, such as the Global, Continental, Sub-Continental or Regional levels (Freeman, 2002). However, some authors claim that the National dimension is not less important in the globalization process context (Amable et al., 1997; Freeman, 2002; Lundvall et al., 2002). The transnational firms' competitiveness will 
increasingly depend on their ability to structure and manage production and marketing international networks. In its turn, research, design, and development activities tend to remain at a National level, at least as long as the Nation is able to provide scientific, technological, educational and financial support, as well as proper communication infrastructure (Freeman, 2002). While production factors are taken into account when it comes to select a location for manufacturing plants, more and more the selection of large transnational companies' research centers are determined by innovation factors (the emphasis is ours), including both quality factors and those concerning the costs to implement R\&D activities, which are components of the candidate country's NIS.

On the other hand, to medium and small companies' competitiveness the National dimension is more relevant. These companies usually account for more than 50 percent of the Nations' GNP (Gross National Product). Moreover, to many of them the best options of formation and/or procurement of human resources, raw materials and complementary resources, distribution channels, and financial and R\&D partners are within national boundaries. According to Lundvall et al. (2002, p. 215) "As long as nation states exist as political entities with their own agendas related to innovation, it is useful to work with national systems as analytical objects".

In summing up the systemic idea of innovation, networks established through the interaction of the various actors in Innovation Systems (ISs) constitute what can be defined as innovation networks (the emphasis is ours). These networks will be the more powerful as stronger is their ability to use communication and information technologies to access, accumulate and apply knowledge (Freeman, 2002). They will be embedded in social systems and sub-systems, being influenced by several environmental factors, such as culture, legislation, educational system, income per head, among others. Again, this unveils the importance of the National Dimension in a globalized economy.

The NIS concept has been the key to explain economic growth sustainability. The major contribution of the NIS approach is possibly concerned with the understanding of the cumulative and systemic character of innovation, clearly indicating the existence of national trajectories strongly influenced by the social/institutional context in which the various agents interact. Thus, while the NIS depends on the nation's trajectory, cultural differences and idiosyncrasies, its performance will basically depend on the level of coordination among its actors.

Nevertheless, the aggregation level of the data usually collected in studies with the NIS approach results in some limitations to the understanding of "how" the firm's interaction with the other elements in the system occurs (Coriat and Weinstein, 2002; Carlsson et al., 2002). Innovation process implies interactions among actors which enable and constrain their action in the search for innovation. Such interactions are not often captured by a more aggregated level of analysis which may lead the National level approach to a static view. A dynamic view of the innovation processes would require an immersion in a more disaggregated level of the innovation system (Carlsson et al., 2002). Beyond more detailed analyses about how interactions between the system's elements occur, this immersion is expected to facilitate the advance towards more specific guidance on public policies, at regional and sectoral levels, as well as on managerial actions at the firm level (Niosi, 2002). Thus, the Innovation Systems approach has been following a theoretical building trajectory that, starting from a broad geopolitical dimension (NIS), has been redirected to other dimensions. From the geopolitical dimension, it was redirected to the regional/local level (Regional Innovation System). Also it advanced towards the sectoral (Sectoral Innovation System) and technological (Technological Systems) dimensions.

In short, the NIS approach has proved adequate for studies on the comparative advantages between nations, as well as for national public policy making concerned with science, technology, industry, foreign trade, and others. In view of the importance of the firm's environment externalities becoming more relevant to the performance of innovations, the theoretical building has been advancing towards more detailed analyses of the mechanisms associated to innovation processes. It is worth to note that besides the merit of having been the forerunner of the Innovations Systems approach, the main claims of the NIS remain relevant in the globalization context. Its application in comparative advantage studies increases in importance, both to firms - especially those advancing in their internationalization processes - and to national governments which are able to make economic policies aligned with the needs generated by innovation processes. 


\section{Regional Innovation System - RIS}

The local dimension relevance to economic theory has been given attention since the late $19^{\text {th }}$ century, with Alfred Marshall as one of its forerunners. To Marshall, "When an industry has thus chosen a locality for itself, it is likely to stay there long: so great are the advantages which people following the same skilled trade get from near neighborhood to one another. The mysteries of the trade become no mysteries; but are as it were in the air, and children learn many of them unconsciously. Good work is rightly appreciated; inventions and improvements in machinery, in processes and the general organization of the business have their merits promptly discussed: if one man starts a new idea, it is taken up by others and combined with suggestions of their own; and thus it becomes the source of further new ideas. And presently subsidiary trades grow up in the neighborhood, supplying it with implements and materials, organizing its traffic, and in many ways conducing to the economy of its material." (Marshall, 1961, p. 225, the emphasis is ours).

In turn, the Innovation Systems approach application in regional contexts gained attention in the late 1990s. In its regional dimension, the innovation system is based on formal and informal networks with geopolitical boundaries, though it is not self-contained and has relations with companies and other organizations beyond these boundaries. These networks pervade companies, suppliers, clients, universities, research institutes, technology transfer agencies, and organizations performing relevant governance roles such as: enterprise associations, chambers of commerce, and others (Cooke, 1997).

The Regional Innovation System approach lies on the understanding of the dynamics of relations between the actors of innovation processes in a given region, regarding their particular features. In The associational economy: Firms, Regions and Innovation, Cooke and Morgan (1998) state that the Regional Innovation System is, in some situations, more important than the National Innovation System. Cooke and Morgan's core argument is that the ability of the actors in a given region to deal with challenges related to innovation and economic development is increasingly dependent on the extent of the inter-firm collaboration and on the ability of regional governments to support these associations and broader collaborative organizations, involving universities, the government itself and other local actors. The authors conclude that even though the national dimension is extremely relevant to innovation, especially concerning public policies (innovation, industry, science and technology, education, among others), it is too broad to meet the specific needs of a nation's various regions.

The Regional Innovation Systems approach (RIS) is relevant both to economically developed regions, since it may help leverage their competitiveness at a global level (Cooke and Morgan, 1998), and to less developed regions. A crucial element to the regional innovation system is the innovation financing, at a regional level. The existence of financial agents that are able to support innovation investments is essential (Cooke and Morgan, 1998). The government performs an important role by fomenting and financing the infrastructure and activities concerned with innovation development, while venture capital funds, both public and private, and other sources of financing are needed to turn innovation diffusion activities more dynamic, as well as to finance the adequate scale of production.

Less developed regions tend to be characterized by a considerably lower coordination and level of interactions between actors (Porter, 1998). In situations like that, governance-related aspects tend to play a significant role. Governance, basically defined as the processes of coordination between the different agents/actors involved, is the basis of what Schmitz (1999) denominates collective efficiency, the gathering of positive externalities with the ability to perform an effective joint action.

The RIS approach has been largely used to understand innovative clusters. This type of approach contains some of the region's cultural particularities like, for example, the sharing of values by organizations and individuals with concern to cooperation, social-mindedness, learning, technology, and relations between universities and the production system (Cooke, 1997). The Regional Innovation Systems of the clusters can be said to be related to a specific institutional structure, motivated by trust and the ability of association and cooperation. In spite of being difficult to measure, social relations exert the greatest impact on Regional Innovation Systems, with a high degree of specialization that is determined by the local/regional economic structure. This degree of specialization justifies and requires a proper public policy making. In that sense, the RIS approach gains relevance 
both to the Federal and to the Regional/Local government (OCDE, 200I).

In less developed countries and regions, policy makers perform an important role by designing and implementing actions intended to bring about innovations of an institutional and organizational nature, which usually precede technological innovations (OEA, 200I). In these countries, there is a greater need to support the coordination of actors, especially by attempting to qualify the interaction between them in order to create levels of trust which facilitate learning in firms and in the region as a whole.

To Chung (2002), the Regional State in the globalized society goes through an increase in importance, since it is expected to promote regional economy more effectively, in terms of systematic promotion of innovation activities. The author still proposes that in the case of developing countries, like South Korea over the last two decades, the effective building of a NIS be accomplished from the development of Regional Innovation Systems, which should be focused on certain industries. Various factors influence the competitiveness of a firm located in a given region that is provided with a well-structured RIS. The following stand out: rivalry between local firms, stimulating innovation; facilitated access to inputs and specialized personnel; facilitated access to information and easy communication; anticipated perception of opportunities; accelerated technological diffusion; complementary character of resources; facilitated access to public organizations and almost public goods; incentives and performance measurement; among others. From this perspective, Chung (2002) delineates a theoretical construct, linking the concepts of RIS, SIS (Sectoral Innovation System) and NIS. In Chung's proposal, the NIS is composed of a matrix of RISs and SISs. Each Regional Innovation System is constituted by one or more SISs, which can be either regionally or nationally wide. Each SIS represents the sum of their regional components and the NIS consists of the gathering of all elements in this set.

From a more critical perspective, according to some authors the rediscovery of the regional is associated with the transformation of regions into a source of capital accumulation through an extraction of unpaid value existing in the externalities and non-tradeable interdependences (Moulier-Boutang, Yann, 2003). These positive externalities consist of factors external to the company that emerge from agglomerated economic activities, such as logistic and infrastructure facilities, human resources, knowledge, and others. The nontradeable interdependences result from interactions between companies and between complementary sectors (technological innovations in a sector that has the power to impact other sectors, relationship network expansion, etc). It is as though the potentialities of a given region's social and cultural fabric could be appropriated by companies and become part of their assets. Thus, the territory as a productive allocation vector presents an integration and interdependence degree so large that it becomes a quasi-firm and a real innovation source. Along with the flexible accumulation process, a form of organization emerges in the social cooperation that is not the market, but that proves capable to generalize externalities (Moulier-Boutang, Yann, 2003).

In short, the RIS approach focuses its analyses on regional aspects that impact the competitiveness of firms, such as natural resources availability, industry concentration, cultural differences, collaboration among local actors, collective learning, among other characteristics that permit a distinction between regions, besides institutional aspects, including public policies and legislation specific to the region. Increasingly, the accumulation achieved by the regional economic trajectory is responsible for bringing about comparative advantages between regions. Moreover, regional aspects become more and more important in systemic innovation approaches, especially because it is at this level that the highest number of interactions among the actors that impact innovation processes take place.

\section{Sectoral Innovation System - SIS}

The sector or industry is a crucial unit of analysis to understand the dynamics of modern industrial economies. The weight given to sectoral analysis by the Structure Conduct - Performance school is justified by the fact that, according to this school, industry structure is the first explanation to understand the firm's performance heterogeneity (Barney and Hesterly, 1996). Even to the Theory of Transaction Costs approach, the sector notion has been basic to develop a growing number of studies on coordination forms in supply chains (hierarchy, market and hybrid forms). One of the most disseminated works is Porter's (1980). It is the five-force model of environmental 
threats (competitors, substitutes, newcomers, purchasers and suppliers), especially designed for the elaboration of sectoral-oriented studies.

Despite the advancements brought about by this approach towards understanding the industrial dynamics, it has shortcomings to explain the innovation phenomenon. Little or no emphasis has been given by such approach to nonfirm organizations, firms' learning processes and, most relevant in the case of a system, to the interaction between agents (Malerba, 2002). Malerba (2002), intending to overcome the gaps in previous Sectoral Systems approaches and, based on national innovation systems literature (Freeman, 1987; Lundvall, 1992; Nelson, 1993), suggests the need of adopting the sectoral innovation system concept.

In a first definition, the sectoral innovation system consists of a set of new or previously existent products, along with various actors that perform commercial and noncommercial interactions to the creation, production and sale of these products. The actors that compose the sectoral innovation systems include:

- individuals (e.g. consumers, entrepreneurs, scientists, etc);

- firms (users, producers and input suppliers);

- non-firm organizations (universities, research institutes, financial agents, syndications and technical associations);

- major organizations' subunits, for example, departments in a company or subsidiaries of multinationals;

- groups of organizations.

Actors share competences, learning processes and a sector-specific set of organizations. The interaction between them involves communication, exchange, cooperation, competition and command processes (in the hierarchical sense proposed by Williamson, 1996). The SIS is structured around knowledge, technologies, inputs and demand related to a specific economic sector. The sectoral system evolution takes place through the co-evolution of its elements (Malerba, 2002). By allowing a better understanding of a sector's innovation, learning and production processes, the sectoral system is complementary to other system approaches such as the national, the regional and the technological approaches. The sectoral system is also mediated by national and

ISSN: 07 I 8-2724. (http://www.jotmi.org)

Journal of Technology Management \& Innovation (C) Universidad Alberto Hurtado, Facultad de Economía y Negocios regional institutions and organizations. It is the case of the national financial and educational systems, legislation on intellectual ownership and labor market. It can be said that the sectoral system is overlapped with the regional and national systems.

The argument that favors the adoption of a sector-specific approach arises from the assumption that heterogeneous firms that tend to use similar technologies, search similar knowledge bases, are embedded in the same institutional environment, share some common organizational features, and develop a similar spectrum of learning and behavior patterns and organizational forms (Malerba, 2002). Such an assumption differs from the Structure-ConductPerformance school tradition which does not deal with this kind of heterogeneity of firms as sector-specific.

More recently, Malerba (2004) has mentioned three sectoral system's dimensions: technological knowledge or command, actors or networks, and institutions. The first, included in sectoral innovation system's previous definitions, concerns the knowledge base, technologies and inputs of the sector. This becomes more complex in the case of sectors whose inputs come from a large variety of other sectors (e.g., health or oil industry). The networks, a term introduced by Malerba, have two essential elements: nodes and flows. In the sectoral innovation system case, the nodes are represented by autonomous agents. The flows are represented by the relations that such agents establish among one another. In turn, the relations between agents are based on communication, exchange, cooperation, competition and command.

The incorporation of the notion of networks in the sectoral system framework is coherent with the fact that innovations more often stem from systematic interactions among a broad variety of actors, intended to produce and exchange of knowledge relevant to innovation. Interactions cover a wide spectrum that goes far beyond market relations and contractual relations of cooperation.

A second dimension of the sector incorporated in the sectoral innovation system network by Malerba (2004) concerns institutions, relatively neglected elements in the Sectoral Innovation System's previous definitions. According to North (1990), institutions, unlike organizations or actors, represent the facilitating elements and restrictions designed by society that shape human interactions. As North's definition might signal a 
predominance of action over the individual, it is worth to remember Giddens' statements (1985), concerning the duality of structure. The structure is both a motivation and a result of social action. The action is produced and, simultaneously, reproduced in the contexts of social life daily production (Giddens, 1985). The conclusion is that the actions of agents from the sectoral innovation system are shaped and shape institutions (norms, routines, habits, established practices, rules, and legislation).

\section{Technological Systems - TECS}

The Technological Systems approach intends a more dynamic view of innovation processes in the sense that it attempts an immersion in a more disaggregated level of the innovation system, paying particular attention to the network of agents that interact in function of a specific technology. The particular institutional infrastructure involving the technological development analyzed, its dissemination and application are analyzed more deeply than in the other IS approaches (Carlsson and Stankiewicz, 1995).

The Technological Systems are composed of networks that are not constrained by the geopolitical dimension, which enables them to gather people and firms from different countries, transcending the National or Regional Innovation Systems' boundaries. The Technological Systems approach also goes beyond the sectoral dimension, in the sense that a technology or product under analysis can be applied in different industries.

Even though the actors of a TECS are basically the same discussed in the other Innovation Systems approaches, more emphasis is given to the firm's (or the system's) abilities to relate with the market. The framework is based on the notion that global demand represents a wide set of opportunities and, as a consequence it guides a specific technological system trajectory. A specific Technological System can be understood as a delimited set of actors systematically interacting to meet certain technological requirements. To Carlsson et al (2002, p.237) “...the main focus is on how well the system can identify, absorb, and exploit global technological opportunities.... This means, e.g. that it may be more important to raise absorptive capacity than to create new technology".

The Technological Systems approach can be applied at different levels of aggregation, from studies focused on a specific technology within a field of knowledge, to a set of technologies that compose a specific product or artifact; or still, a set of products designed for a specific economic function (Carlsson et al, 2002).

After defining Innovation Systems (National, Regional, Sectoral and Technological), a question arises: which approach (or approaches) would be indicated to study the case of a subsystem characterized by a set of actors that include firms from various sectors located in a specific region and interacting to gain competitiveness through various innovation projects and various cooperative market efforts focusing one global industry as oil and gas industry?

Possibly, the recommended course of action is to conduct the study through a multi-dimensional systemic approach. It would permit an understanding at the level of coordination of the interactions between the elements of the several levels of the Innovation Systems involved. It should be noted that the case is not broad enough to characterize a RIS; even though the supplier firms belong to several economic sectors, it does not follow that they cover all relevant sectors of the region. Nor is it broad enough to characterize a SIS since it is focused on a single region, not to mention that the firms belong to various sectors. At the same time, the TECS approach appears to be very restricted, since the variety of products supplied to the oil and gas industry is very large. It can vary widely both from the technology used and the application of the products supplied.

The Innovation Network concept presented next may indicate a fruitful alternative to approaching cases such as the above mentioned, without losing sight of the systemic aspects of approaches discussed so far and taking into account the central elements of each approach. Furthermore, it allows an advancement towards the detailing level of interactions between actors and coordination of actions, as well as of innovative projects and the relationship among them.

\section{Innovation Network - IN}

The concept or notion of innovation networks is often shadowed by the recent evolution of the Innovation Systems' concepts. This is especially true when a broader notion of innovation networks as processes of interaction among heterogeneous actors, producing innovations at any 
level of aggregation (regional, national, global) is given. Basically, interaction processes among heterogeneous actors occur in innovation systems, even though, in the innovation systems approach, the main concern is the ability or the elements necessary for the company to innovate. From the point of view of public policies, innovation systems deal with innovation processes in a generic way and to what extent this affects the economic development of a country, region, sector or set of actors focused on a technology, product or specific application.

The theoretical building behind the notion of innovation networks dates from the 1980s. Then, the word 'network' became a powerful metaphor to explain the characteristics of various economic phenomena, such as regional agglomerations and the user-producer relations in the supply chains (DeBresson et Amesse, 1991). The network analysis attempts to seize the configuration, nature, and contents of a set of inter-organizational relations (DeBresson et Amesse, 1991). It is a way to see the multiple relations existing in economic activity. In this case, configuration has to do with the morphology of those relations or how the network's nodes and links can be viewed. The nature concerns the type of relation (commercial, technological, financial or productive) and the contents concern what is exchanged among network members (information, tangible assets, work division, common aspirations, etc).

The innovation networks' object of study is characterized by inter-organizational networks, especially involving innovative companies, in addition to other actors like government, universities, research centers, and financial agents. Even this delimitation is not enough, since these networks contain the networks of user-producers, regional inter-industrial networks (existing in the regional agglomerations), strategic alliances in new technologies, etc. (DeBresson et Amesse, 1991). The network configuration might be present even in dyadic relations (between two companies), including supplier companies and the relations involving the organization's different levels. For innovation networks, the firm or inter-firm relations constitute the locus of innovation.

The technological transactions have features that present implications to the Theory of Transaction Costs, such as asset specificity, tacit nature of knowledge, technological uncertainty (feasibility of the technological solution found) and market uncertainty (new product or service acceptance), and the uncertainty connected to the innovation appropriation (to what extent it is possible to set barriers to keep competitors away from rapidly appropriating the innovation produced). In view of the uncertainty that characterizes technological innovation, the internalization (activities performed within the company) appears to be the best course of action to reduce transaction costs. Nevertheless, this is not always the case and the networks end up becoming an alternative to the 'make or buy' dilemma. The inter-organizational linkages that occur in the networks are appropriated to the technological transactions. For Debresson and Amesse (1991), transaction costs approach to network innovation has two important limits.

First, the little attention given by this theory to the trust construct as a form of governance (or how companies manage their relationship when developing joint activities), considering formal and informal relations. This is especially true as trust derives not only from a rational calculation of the actor (Williamson, 1996), but also from shared norms and values, besides the reputation and legitimacy of certain actors (as in the case of governments, development agencies and financial organizations). In turn, norms and values that make trust a central form of coordination among actors in the network derive widely from a discursive negotiation. The networks are dominated by another type of social integration, other than hierarchy or formal contract, or still coercion. The discursive negotiation implies consensus and legitimacy building by means of convincing rather than controlling on the part of an actor who holds a more significant amount of resources than the others.

Second, the emphasis placed on the reduction of transaction costs misses other benefits from the network cooperation, such as knowledge creation, development of competences and the social learning important to a region or industry development.

The trust-based coordination between actors indicates an increasing share of goals, senses, behavior standards and values (Nooteboom, 2004). A cognitive and generalized basis shared by actors contributes to establishing a "savoir faire" in the innovation network activities management. The trust-based coordination often counts with intermediate organizations such as development agencies, 
enterprise associations, and government agencies. Some of the roles these intermediate organizations perform in the networks are: to facilitate communication for a mutual understanding between the actors, to cut down the cognitive distance among them, to monitor the information flow and to operate as an intermediary in trust building (Nooteboom, 2004).

The innovation networks are similar to the technoeconomic networks. These are defined as a coordinated set of heterogeneous actors that collectively participate in the conception, development, production and distribution of goods and services (Callon apud Green et al., 1999). Some authors have used the techno-economic networks concept to understand the dynamics of relations between the innovation system's actors (Kumaresan et Miyazaki, 1999; Green et al., 1999). The innovation system analysis, as seen by the techno-economic networks approach, permits the description of the dynamic relations between the various actors, processes and equipment necessary to the success of an innovation.

The concept of techno-economic networks refuses to consider the firm, university or consumer as the reference unit, but rather considers as such the system of coordinated links existing between the different actors (Kumaresan et Miyazaki, 1999). Like the innovation networks, the techno-economic networks presuppose coordination and relations between the innovation process actors. However, there are important differences between both concepts. In the concept of innovation network considered here, the network is not necessarily linked to a technology, sector, product or family of products, but can be formed from companies of various sectors and with very different technological bases. In the innovation networks approach, the core concern is with the management of resources like knowledge and information useful to innovation, including market information. An innovation network may contain various techno-economic networks; at the same time, they might transcend it in the geopolitical dimension. And, as far as this work is concerned, an important difference is the fact that technoeconomic networks tend to be formed and developed spontaneously, while the innovation networks can be induced, especially by government policies.

Küppers and Pyka (2002) statements are valid for both techno-economic and innovation networks. Network structures link the diverse knowledge of producers, suppliers and users located in different organizations, and that those structures facilitate the rapid information exchange and joint decision-making processes. It is worth to mention that in innovation networks, many actions of collective interest developed have not a technical nature and are not directly associated with specific innovation processes; rather, they correspond to processes of an organizational nature and institutional building. In other words, actions relative to specific innovation processes are usually of interest to a small network group, which may however involve actors from different dimensions of the Innovation Systems belonging to the network.

A strong motivation to the formation of innovation networks has to do with the complexity of the knowledge base required to innovate. This is especially true in areas such as biotechnology, nanotechnology and robotics. The knowledge base complexity makes it extremely difficult to create the necessary knowledge within the boundaries of a single firm. This, in addition to the dispersion of knowledge sources, places networks, rather than individual firms, the locus of innovation (Powell et al, 1996). However, it is important to have in mind that this in no way reduces the company's knowledge base and internal capabilities importance, for according to Powell et al (1996):

"Internal capability and external collaboration are not substitutes for one another, but complementary...internal capability is indispensable in evaluating research done outside, while external collaboration provides access to news and resources that cannot be generated internally...A network serves as a locus because it provides timely access to knowledge and resources that are otherwise unavailable" (Powell et al., 1996, p. 119).

Another motivation to the formation of innovation networks is the reduction of uncertainty inherent to innovation. They may be an answer to reduce the innovation process uncertainty and degree of irreversibility, lowering the cost and risks of a new field of knowledge development, increasing the commitments' flexibility and reversibility and reducing the market information asymmetry. This is reinforced by authors that analyze the network organization paradigm to the innovation in regional agglomerations (Cooke, 1996; Rothwell, 1996). 
Powell (1998) stresses that a spectrum of organizational linkages is critical to knowledge, learning, and technological development diffusion. The network configuration connections may occur through formal contractual relations, as in the case of the R\&D partnerships and jointventures, or informal relations as in the communities of practice. Both mechanisms are relevant to knowledge transfer and reinforce one another.

Unlike innovation systems, innovation networks are not systems with interdependent elements defined a priori; rather they constitute auto-organized social structures that are created in an unstable situation because the actors involved (companies, universities, government agencies, and financial agents) have not been able to define the innovation problem or its solution (Günter and Pyka, 2002; Günter, 2002). The self-organized social structure that characterizes the innovation network implies a complex coordination of countless interdependent and complementary activities among the actors of an innovation process. Thus it is important actors that establish exchanges among themselves share a perception of belonging to a certain space or group and be able to perform joint actions, even if only potentially. Therefore, it can be concluded that the boundaries of innovation networks, unlike innovation systems, are innovation projects shared by firms and other actors. In other words, the notion of an organization belonging to a certain innovation network is established by the existence of innovative activities, performed along with other firms and organizations involved in the different stages of innovation (financing, commercialization, product development, basic research, market knowledge, and production). These activities, especially the collective ones, may also involve action of a broader institutional nature, reflecting over innovation processes.

The networks have also features that result from their own structural characteristics. There may be more or less information diffusion in a network, not only because of a similarity to hierarchy or market relations, but because there is a greater density or connectivity among its actors that hierarchy and market fail to capture. The network morphology has a repercussion on the development of interdependent economic activities, which goes unnoticed when treating it as merely a hybrid form between hierarchy and market. Beyond this morphology, it is pertinent to examine the contents of linkages and flows between the actors, who decides on these flows and based on which interests, which resources are available to these flows, how the linkages are created and why they are maintained (Powell and Smith-Doerr, 1994).

As they become a mechanism for innovation diffusion through collaboration and interaction, innovation networks emerge as a new form of organization directed towards knowledge production. They present three key implications (Kuppers et Pyka, 2002): (i) they constitute a coordination device that both enables and supports intercompany learning; (ii) they permit the exploitation of complementarities, which is essential to dominate technological solutions characterized by the complexity and diversity of knowledge areas involved; (iii) they constitute an organizational (or inter-organizational) environment that makes it possible the exploitation of synergies by bringing together different technological competences.

As in the network coordination (Lipparini and Sobrero, 1997), the main coordination mechanisms of innovation networks are the following: a) mutual and direct adjustments between the parts by joint decision-making in equality terms (all actors have the same decision power) and with no protections or explicit contractual certifications; b) adjustments and coordination of network activities are supported by a third party that mediates and facilitates network relations; c) multi-degree delegation of coordination and control tasks to a central authority or broker; d) institutionalization of a rules system and control tasks among the firms and other actors, be they formal (contractual) or informal rules (sharing norms and routines).

There are at least three factors present in the formation of innovation networks. One is the geographical concentration of firms from the same industry or complementary industries. In this case, innovation networks are derived from an innovative millieu, wherein the knowledge spillover takes place and from the cooperation motivated by a region's trajectory, in a political and cultural sense. Another process is the existence of complex projects involving the development of products with a highly technological content. One example is the R\&D consortiums aimed at the development of commercial and military planes. Less investigated than the other factors, the innovation 
networks might also result from induction, either by the State through a specific public policy or by a set of associated firms, with the aim of enhancing both the interorganizational cooperation and the cooperation with other organizations in the country's technological infrastructure (such as universities and technological centers). In other words, firms and other actors of Innovation Systems are motivated to cooperate and coordinate complementary activities in one or more sectors covering the innovation process' different dimensions. The last factor is especially relevant in the context of newly industrialized countries and/or regions, with a more fragile technological infrastructure and not many innovative companies.

\section{Induced Innovation Network (IIN): A Conceptual Framework}

The underlying assumption of this framework is that interactions among actors that participate in specific innovation processes can be enormously improved by induced coordination mechanisms. In this sense, firms' innovativeness and the innovation processes performance can be increased by means of an ex ante institutional design, which is able to induce the creation of an innovation network as previously defined. The network's purpose is enhancing the collective effectiveness of innovation systems. The Induced Innovation Network IIN - is the element that seeks the synergy between the actors of these systems in order to make a more effective use of resources in innovation processes at the firm level. This strategy appears to be especially relevant to innovation policies in countries and regions where the sectoral innovation systems are not developed and where the economic fabric is not so dense.

The IIN has a Coordination Center whose main attributions are the selection of members, intermediation of cooperation relations and support to decision-making on the form and content of such cooperation. Essentially, the Coordination Center plays a role as mediator and facilitator of network relations. In more mature systems, with a denser economic fabric, this coordination role is facilitated and is often performed by specific sectors of large companies and/or associations of firms or, still, by brokers. Such attributions allow the IIN play two crucial roles; increase competitiveness by supporting innovation and providing market opportunities by supporting relationship with large customers.

The framework picture can be viewed in Figure I. The Induced Innovation Network coordinates the Innovation Systems' actors both to specific innovation projects, involving two or more actors, and in actions of a broader collective interest such as market prospects, representation towards other IS actors that are external to the network (including potential clients with a high purchase power), organization of events, qualification of human resources, technical-commercial missions and marketing.

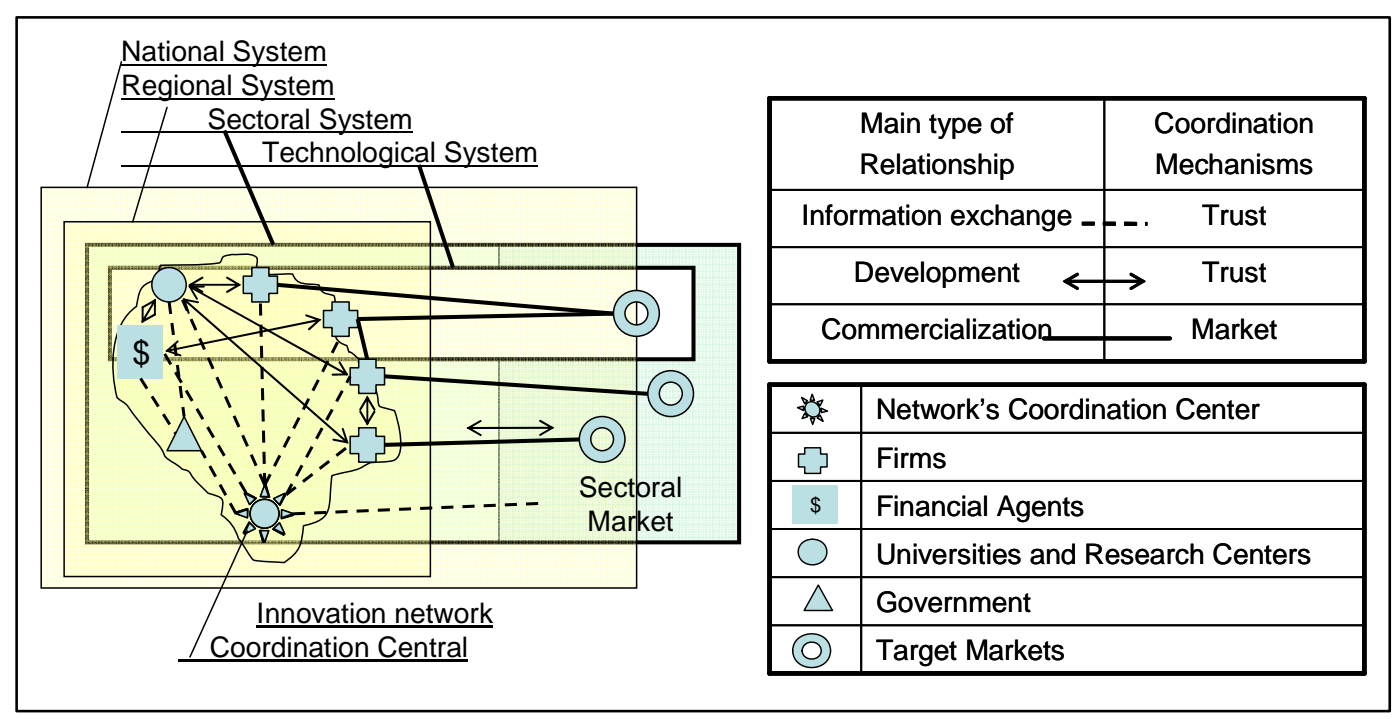

Figure I. Conceptual framework of the Induced Innovation Network 
Figure I illustrates the main types of actors present in an Induced Innovation Network, in addition to the main types of relationship between these actors and, still, the main coordination mechanisms involved in these relations. The Figure also demonstrates that the IIN members are embedded in an institutional environment structured by elements from the National and Regional Innovation Systems. The market validating the new products and services of the network firms is an essential element, since it sets the boundaries of the industrial sectors on which the Coordination Center will focus its efforts of planning and development of collaborative activities.

Different actors play different roles in an innovation network. Government, firms, universities, research centers, and financial agents are actors with different aims and may contribute differently to the success of the IIN. If, on the one hand, the differences between actors may be seen as potential complementarities, on the other hand the exploitation of potential synergies requires a greater ability of coordination between them, reinforcing the idea of a Coordination Center in the IIN.

Among all types of actors involved in the IIN, the local government appears to be the actor whose nature and mission are the most aligned with collective action, given its interest to rise firms competitiveness as a whole through the innovation rate increase. Thus, the government can perform, in some situations, the role of representative of the collective interests in relation to other government instances, financial agents, high administration of large corporations, governments from other countries or regions, among others. The government, while an actor from a formal or informal innovation network, grants legitimacy to it towards external actors. It is also the most prepared actor to safeguard the collective interests from the network with regard to public policies and has the ability to better design local public policies in order to provide support in overcoming restrictions that might be imposed to the dynamics of innovation processes.

Another aspect that induces the government to be a more collective actor has to do with industrial policy making. The local government is also the actor with more access to the National Government bodies, where most of rules and policies that impact firms' competitiveness are made such as: i) legal framework of the country (e.g. property law); ii) specific regulations of the sectors the firm is directly related to (e.g. supply of raw materials and other materials, specific industry where it acts, client industry); iii) Research \& Development system; iv) educational system, etc. Thus, the Local Government can take on the role of inducer of public policies related to IIN, even if they are the under the responsibility of the national government.

Innovation processes are increasingly more complex and may be expensive, requiring from firms a greater capability to make use of external resources, like knowledge and financial capital. They result from the application and combination of the firm's internal and external resources. Based on the proposition of Eisenhardt (1985), according to which the added value achieved by using a resource is not directly associated with this resource's intrinsic value, but rather with the service rendered, it would be reasonable to suppose that the use of the firm's internal and external resources would depend on its ability to extract from these resources the level and type of services more adequate to its purposes. A common characteristic in innovation processes is the explicit linkage between the firm and sources of knowledge available outside it (Eisenhardt and Martin, 2000). These processes tend to become a strategic intention on the part of the actors involved, which intensifies the firm's interactions with the other actors in the system and promotes an evolution of the innovation network institutional environment.

Part of the knowledge resources and R\&D capabilities necessary to firms can be found at Universities and Research Centers. These organizations usually count with specialized competences and have updated information on technological development at a global level. Hence these actors are given the central role of knowledge transfer to firms and cooperative participation in projects, especially involving qualified human resources, testing equipment, research methods and techniques, development, tests, simulation and prototyping, besides the technological knowledge itself.

In the realm of the IIN and projects that involve various actors, it is the role of financial agents to structure the financial engineering of enterprises with an aim to make them feasible, minimizing the financial risks associated. They structure funding to trigger off innovation processes, 
as well as risk capital investments; also, lines of financing for a production scale adequate to successful projects.

To a more efficient and effective development of innovation processes, roles and interests of the various types of actors should be coordinated and the resources available combined in a synergic way. Negotiations among actors, during innovation processes, should not take a hierarchical form and should not be subject to market relations exclusively. There is the opportunity and the need of practicing a discursive negotiation to ponder the relations among actors, which implies in the need of creating conditions to their effective engaging in the Innovation Network. This systematic role of sensitizing and coordination of collective interest actions or of a specific set of actors (as in case of a specific project) belongs to the network's Coordination Center. The Coordination Center performs the important role of reducing the complexity in the relationships between the actors and also of the risk associated to innovation, in the sense proposed by Kuppers and Pyka (2002). It can be said that the Coordination Center complements the firms' capabilities concerning the need of developing a higher number of more qualified interactions with the other actors in the Innovation Systems.

To illustrate the framework proposed, the case of the PETRO-RS Network is presented. An innovation network which resulted from an action that originally involved a set of firms and the state government of Rio Grande do Sul. This network was intended to develop innovations in products and services and thus meet the demands of the Brazilian oil industry whose diversity of opportunities has been greater than in any other industry in the country.

\section{The Wide Array of Opportunities in the Brazilian Oil Industry}

With regard to the demand of products to the oil industry, the study "Selling to Brazil - a Practical Guide for British Oil \& Gas Sector Supply Companies" of the British Trade International/Energy Industrial Council of 2002 (EIC, 2002) presented estimations of oil companies' global investments. The numbers were US $\$ 200$ Billion a year, in this early $21^{\text {st }}$ century. That document recommended that United Kingdom suppliers, with tradition in supplying products to the oil sector offshore, concentrated their selling efforts in three "key geographical areas": Gulf of Mexico, Western
Africa and, especially, Brazil. In the publication "World Energy Investment Outlook 2003" of the IEA International Energy Agency (IEA, 2003), the estimation of total investments in this sector in Latin America - AL Between $200 \mathrm{I}$ and 2030 sums up to US\$ 583 Billion. From this amount, investments in product acquisition to offshore applications are estimated in US\$80 to 100 Billion a year between 2005 and 2009 (Mikkelsen et al. 2004).

The América Economia publication (2004) about the 500 largest public and private companies of Latin America revealed that oil industry state-owned companies ranked in the top 4 most profitable: PEMEX (US\$ 55.7 billion), PDVSA (US\$ 46.0 billion), PEMEX Exploración y Producción (US\$ 37.9 billion), PETROBRAS (US\$ 33.1 billion). Together, these three state-owned companies (PEMEX, PDVSA and PETROBRAS) will be responsible for about 60 percent of investments in Latin American oil industry this beginning of century. Other information sources in Brazil, like the ONIP ${ }^{5}$ and the PROMINP ${ }^{6}$ estimate investments in the country to be around US\$ 10 billion a year up to 2010. About 70 percent of the investments will be concentrated on Offshore Exploitation and Production. In this area, it will be also relevant the investments in the Western Coast of Africa. Recent discoveries of deep-water fields in Nigeria, Gabon, Congo, Guinea, and Angola allow estimates of product demand to exploitation and production around US\$10 billion a year in a near future.

The total amount of worldwide investments estimated by the Brazilian state-owned Petrobras to 2004-2010 is of US\$ 53.6 billion (Barusco, 2003). From these numbers, Petrobras expects to achieve a nationalization rate of approximately 65 percent, what would represent a supply potential of approximately US $\$ 34.8$ billion to Brazilian firms. Petrobras' estimated investments in Brazil alone (US\$ 46.1 billion) would correspond to at least US $\$ 30$ billion in supplies by firms established in Brazil. Furthermore, other oil companies had enterprises in Brazil announced. From 2003 to 2007, the amount of external oil companies' investments in Brazil is estimated to be approximately US\$ 6.4 billion (Teixeira, 2003). With regard to financing, over 60 percent of Petrobras'

\footnotetext{
${ }^{5}$ ONIP - Oil Industry National Organization http://www.onip.org.br

${ }^{6}$ PROMINP - Mobilization Program for the Oil and Gas Industry - http://www.prominp.com.br
}

ISSN: 07I 8-2724. (http://www.jotmi.org) 
investments will be financed by Brazilian funds, involving: i) Petrobras' own funds; ii) funding sources from national financial agents; iii) Petrobras' capital increase. The two types of financing, by own capital and by capital from national financial agents, increase the expectation of supplies on the part of companies established in Brazil. This is derived from a usual practice in the international market, according to which financing in this industry is usually coupled with buy-out bonds for a major part of the products in the countries that fund such investments. Furthermore, it is possible that the national industry that supplies the Petrobras benefits from those actions, facilitating their insertion in the supplies to the investments intended by that state-owned company outside the country. These are estimated to be US\$ 7.5 billion in 2004-2010 (Barusco, 2003).

In order to increase the presence of Brazilian firms in this sector and, as well, to replace imports, the Brazilian government has been announcing programs of support to investments in new product development. One of the government's initiatives to enhance oil industry's national competitiveness was the creation of the CTPETRO, in 1998. This is a fund for the oil sector intended to form human resources and foment Technological Research in the sector. Another important initiative was the creation of the National Oil Agency (ANP) that, from the opening of the Brazilian oil market in 1999, has been regulating the Exploitation and Production Operations (E\&P) in the country. One of the ANP's mechanisms to stimulate national suppliers in this industry has to do with the commitment to a larger amount of technological items developed in the country in the procurement of firms carrying out E\&P operations. Furthermore, three nationwide programs were implemented in Brazil in 2003. They are related to the development of suppliers to the oil sector, as follows: Brazil Technology Network - RBT (Ministry of Science and Technology), focusing on the development of supplier networks; the PROMINP (Ministry of Mines and Energy), developing institutionalrelated actions to support the increase of supplies by the national industry; the REFORMASGAS - a Petrobras program to structure and qualify a national supplier network to the natural gas industry.

These efforts, involving different government instances in addition to Petrobras, private companies, and organizations that provide technological and financial support, may contribute to the development of a more adequate environment for firms established in Brazil concerning the access to supplying for the oil industry. In addition, being the Petrobras one of the main offshore oil producers in the world, the competencies and the technological capability required from its suppliers create objective conditions to the insertion of Brazilian companies in the global market. As they establish closer relations with Petrobras, these companies have access to qualified information that contribute to their process of adaptation and reconfiguration of organizational abilities necessary to obtaining a competitive advantage based on the supply chain.

\section{Innovation Networks focused on the Brazilian Oil Industry}

PETRO-RS Network - Technology-Based Network of Suppliers from Rio Grande do Sul State to Gas and Oil Industry - was created in 1999. This was a pioneer undertaking in Brazil and its beginning was encouraged by the following factors: (i) existing demand in the oil industry and (ii) country-related comparative studies, in countries like Norway, England and Scotland, Canada, and others (ANP, 1999). The former experiences in networks from oil and gas upstream firms took place in countries with mature national and sectoral innovation systems with many competitive firms, (iii) the existence of firms in a wide variety of industries in rio Grande do Sul State - RS - such as metal mechanic, electroelectronic and software able to become suppliers from the oil and gas companies and (iv) the existence of a political institutional environment in RS that favored the formation of innovation networks. ${ }^{7}$

The creation of the PETRO-RS Network was conceived by a group of 10 companies that supplied Petrobras, whose aim was to develop new products given the existing technological demand gap from upstream firms located in Brazil. It is worth to note that these 10 companies had practically no relations with each other and belonged to different sectors, involving the supply of various products such as anchorage cables, engineering services, valves, automation software, submersible pumps, drilling tools, forged metallic components, hydraulic actuators, programmable controllers, cast metallic components, among others. The common feature between those

\footnotetext{
${ }^{7}$ For further information on the PETRO-RS Network see http://www.sct.gov.br/petro-rs
} 
companies was the perception of the existence of a series of opportunities in the oil industry. Such opportunities could be achieved by expanding their network of relations with other firms, universities, and with the Petrobras through a new institutional and organizational arrangement. The government of Rio Grande do Sul, sponsoring the idea, offered decisive support in the PETRO-RS structuring by establishing a Coordination Center to the network through a program developed by the Science and Technology Office from the State of Rio Grande do Sul. The government's enterprise facilitated the sensitization of other government instances, universities, financial agents, the Petrobras, and new supplier companies. It can be described as a government-induced movement, jointly with some supplier firms, which soon involved other actors that could contribute for innovation processes.

The PETRO-RS Network's basic idea consists of promoting coordination among different types of actors, with an emphasis on the following: supplier firms, government, universities, technological centers, financial agents, and support organizations. The aim was to effectively develop innovation processes to meet the market requirements (especially the Petrobras). The Network's main objectives are: (i) to develop technology in Rio Grande do Sul meeting the needs of companies in the oil and natural gas sector; (ii) to get firms closer to local research centers and enhance agencies, with a view to developing or consolidating technology with a high added value to these companies; (iii) to qualify and equip research centers in Rio Grande do Sul, especially through developing applied research; (iv) to broaden market possibilities to companies from Rio Grande do Sul, gaining strength and branching out business operations. For this reason, in addition to a yearly-reviewed strategic planning process, the PETRO-RS systematically develops two types of projects: collective and private. The results of each collective project have a potential reach for all network members. Some examples: market prospects, seminars, participation in technical events, business networking, fairs, among others. The results of private projects have a direct reach restricted to those taking part in them. However, other actors in the network may benefit from them indirectly.

The Coordination Center - CC - seeks to facilitate the use of external resources by firms so they can rapidly and flexibly respond to business opportunities in the sector, through the carrying out of collaborative actions. Resources made available to firms in the network involve mainly: (i) more qualified information on technological and marketing trends; (ii) technological and scientific knowledge present at universities and technology centers; (iii) qualified relationship channels with other supplier firms, with Petrobras, financial agents and the federal and state governments. It can be said that the resources available to firms optimize their innovation processes. For example, the inter-relationship between firms and the Petrobras has tended to become more effective with concern to the identification of suppliers for new products and/or the replacement of imports. Various projects in this line have been developed. In addition to facilitating interactions between actors, the CC performs the role of searching, centralizing and distributing information. Also, firms in the network send information they wish to share to the Center. It is information on market, financing and funding sources, new technological developments, events, relevant news, among others. The participation of the network's executive coordinator in events and the qualified relationship network that has been developed by the PETRO-RS have a multiplying effect on information getting to the firms.

This model is strongly trust-based, both between firms in general and the Coordination Center, for actions of a collective nature, and between some firms and other actors, in the case of specific projects. As the network expands, there is a growing number of firms interested in the same target market, accessing the same information and projects, which is positive since the internal competition in the network also fosters innovation. In this case, rules are clearly spelled out: when the CC identifies a potential project for the network's firms, this information is made available to all members. Those interested in meeting the demand are put into direct contact with the customer (e.g. Petrobras). At this moment, the CC withdraws and the selection of the firm or set of firms that is to develop the project will depend on the direct negotiation established and on the customer's final word. After this definition is made, the CC can resume the support of the process, pointing researchers, labs, consultants, and other actors in the network that may collaborate in the project, complementing the resources required. If necessary, the $\mathrm{CC}$ also facilitates the contacts 
with financial agents and provides guidance on supportive public funds.

As a coordination mechanism, the PETRO-RS Network can be understood as a space for linking and exchanging information and knowledge between the different actors involved in the innovation processes. From the perspective of coordination, it is important to emphasize that the presence of the state government of Rio Grande do Sul in the network provides legitimacy to reach senior management from PETROBRAS with the highest decision power in Brazil and abroad. This notion can be illustrated with the various meetings held by PETRO-RS executives with the board of operations from Petrobras, or still with the directors of procurement and research of the company. Such meetings resulted into cooperative projects and guidance for other partnerships.

With regard to the PETRO-RS Network's action results, it is important to make a division between: i) actions whose focus is directly connected with the individual performance of firms and research labs acting in Rio Grande do Sul; ii) expansion of the network itself in the Rio Grande do Sul and of its reputation to other Brazilian states.

Concerning the efforts towards the enhancement of the firms' performance, the following accomplishments can be mentioned (Balestro et al., 2003):

- Development of new technologies and products, through projects of cooperation between firms, universities, and research centers that form the network with support from financial agents. Platform anchorage components, software, electronic equipment, control systems, natural gas energy generators, valve automation, pumping units, sucker rods, biodiesel fuel blends, are some examples of products owing their development to Petrobras' demands.

- Studies and research projects involving nanostructured materials, geological formations, besides structuring of new research labs and infrastructure updating in existing labs; qualification of human resources and researchers; qualification of sub-suppliers; development of service rendering labs.

- Marketing studies and support to the participation of Rio Grande do Sul firms in international fairs as visitants, as well as expositors in international events with shared stands; international missions for catching international market prospects, with trips to Bolivia, Venezuela, and Argentina.

- Visits to different companies and regional universities' labs, promoting partnerships between the academic and the enterprise sectors aimed at technology development and the creation of new internal supply relations in the network.

Through PETRO-RS Network, many firms in Rio Grande do Sul came to consider the supply to Oil and Gas Industry as an opportunity to diversify their operations on the market. By viewing the market potential and helped by trade promotion activities performed by the Network, they started to define their strategies with priority given to the oil industry supply.

In the early 2005, one hundred and ninety companies (suppliers and sub-suppliers) and over 90 research labs were members of the network, besides the Petrobras and the financial agents. Furthermore, in this period more than 40 technological development projects were carried out, "pulled" by demands presented by the Petrobras.

The examples of projects developed by firms and the perception by entrepreneurs of the importance of the PETRO-RS Network in supporting innovation processes were evidenced in field research carried out in the network's companies in 2005. Gains were observed in connection with the enhancement of relations between the companies and Petrobras, both those based on knowledge exchange, especially in collaborative projects, and those based on business relations. In the case of product development projects, optimization and qualification have been observed in interactions among firms, as well as in interactions of firms with labs and researchers from universities and research centers. It was also observed a rise in the use of public funds to R\&D by firms and universities, besides a new position assumed by researchers in the sense of giving more importance to the generation of patents, in addition to publications.

With regard to the expansion of the PETRO-RS Network's concepts, emphasis should be placed on the support given to the structuring and launching of the PETRO-BC Network in Bacia de Campos, Rio de Janeiro, 2003. It is relevant to mention, as well, the creation of the so-called Brazil Technology Network (RBT) nationwide by the Ministry of Science and Technology, also in 2003. Its 
primary goal is to promote an effective coordination among the different areas of the Federal Government, Brazilian universities, private companies, and financial agents. The RBT's mission is to help building a favorable environment to applied research, technological development and qualification to the local production sectors. One of RBT's target sectors is the Oil and Natural Gas Industry, to which the PETRO-RS model has been seen as national reference. Motivated by the creation of the RBT and PETRO-RS model, such networks were structured in various other states from Brazil.

Such a dissemination, which was the aim of PETRO-RS since it began operating, is strategic, since the performance of the innovation processes developed by the PETRO-RS actors largely depends on national and sectoral institutions. It depends, also, on the regional institutions and on clients from other regions in the country. Finally, it means a great contribution to strengthening supply chains in Brazil and to the maturation of the Innovation Systems in the country.

\section{Conclusion}

One of the benefits of this article was advancing the conceptual distinction between the different innovation systems and innovation networks, stressing the interdependence and complementary nature between them. On the one hand, the innovation systems approach focuses on the elements that facilitate innovation from a broader political and economic perspective. On the other hand, in innovation networks the focus in on the coordination of action required to innovate, where the contents of interactions is associated with the set of interdependent and complementary activities to perform innovative projects.

The three factors usually present in the formation of networks are: (i) geographical concentration of firms in a same sector or complementary sectors, where cooperative relations giving rise to the networks are formed from a region's evolutionary trajectory, in a political and cultural sense; (ii) the existence of specific complex projects, involving the development of products with a high technological content and requiring collaboration between firms and/or between among types of actors and (iii) the induction of cooperation by means of public policies or initiatives on the part of intermediary organizations, such as business associations that identify interests that are, either general or specifically, common to a group of actors. These factors may appear in a combined way. In the case of the PETRO-RS, for example, the induced innovation network and a set of specific complex projects coexist. They are developed by specific subgroups of actors, with the network's institutional support.

The Induced Innovation Network grows out of a deliberation from one of the actors that will take part in it. Such a deliberation is associated with a cooperation design established ex ante, modified and adapted according to the network's trajectory. It may start with the government, business associations, or groups of companies with common interests, for example in the supply to a particular industry. For the latter, firms may also belong to different sectors, as in the illustrated case whose interest is the oil industry supply.

The article presents two important implications both to policy-making and to the understanding of innovation processes that take place in environments with multiple actors. The first concerns the induction process in the network formation. In spite of the well-established role of public policies and the government in facilitating innovation networks, little has been said about how they can effectively induce the formation of these networks. The second is concerned with the coordination of actors. The framework and the case discussed intend to describe not only the actors and the main interactions between them, but also some aspects of the coordination mechanisms that characterize them. Moreover, the notion of "Coordination Center" described in the article, along with its attributions and the way it works, indicates a solution to the problem of coordination in the innovation networks. More than understanding the motivation to cooperation, the main concern is to understand the challenges of cooperation management, especially in the case of innovation-oriented cooperation.

The framework can be possibly used, also, to analyze the process of induction of an innovation network in other contexts of supply chains from capital-intensive industries. The fact that these industries involve a large variety of sectors makes the Induced Innovation Network experience important to the making of sectoral industrial policies in developing countries and/or regions, with repercussions for the technological basis. In theoretical terms, experiences like these represent great challenges to 
the institutionalization of this type of network. The design of the public policy that begins an innovation network, as well as its initial shape, needs to go through an institutionalization process so that the sustainability of this type of arrangement may occur. Having that in mind, it is essential to understand how trust represents a coordination mechanism and to what extent it may result from a discursive negotiation between actors with different interests.

A key aspect to be analyzed in relation to the coordination center role concerns the legitimization of this center with regard to the network components, and its mediation in the collective decision-making process. The Coordination Center legitimacy is very important to the institutionalization of a system of rules and control tasks between the companies and the other actors. This is true both to the formal (contractual) and the informal rules (sharing norms and routines). As long as the coordination center performs roles that are complementary to the firm, concerning its articulation with other actors, it is required that the center itself develops a set of capabilities, above all those of relationship management (relational capability), knowledge management, and project management.

Finally, the case of the PETRO-RS Network has been generalized to other Brazilian states. Possibly, it may be generalized to other regions, in other countries, that are able to take advantage of a window of opportunities by capital-intensive industries, as in the case of oil industry. This industry has a multi-sectoral supply chain, with a large technological diversity. A high number of the supplier firms also deal with other industries, so that part of the innovations developed to a given sector ends up benefiting a wider scope of users.

There are, as well, other industries provided with multisectoral supply chains. They are, possibly, more promising than the oil industry concerning technological challenges, like health, pharmaceutical and food industries, among others. Also in these cases, the induced innovation networks approach may be an appropriate tool to support the competitiveness of firms, especially of those inserted in the contexts of less mature innovation systems.

\section{Knowledgements}

This paper was supported by CNPq - National Council for Scientific and Technological Development - a foundation linked to the Ministry of Science and Technology (MCT) to support Brazilian research.

\section{References}

AMABLE, B., Barré, R., Boyer, R. (1997). Les systémes d'innovation a l'ére de la globalization. Economica, Paris.

AMÉRICA ECONOMIA (2004). 500 maiores empresas da América Latina. América Economia. Chile.

ANP (1999). Mecanismos de Estímulo às Empresas Concessionárias de Petróleo a adquirirem Equipamentos, Materiais e Serviços no Mercado Nacional. ANP, Brasil.

BALESTRO, M. V., Antunes Jr, J. A. V., Lopes, M. C., Pellegrin, I. (2004). A experiência da Rede PETRO-RS: uma Estratégia para ○ Desenvolvimento das Capacidades Dinâmicas. Revista de Administração Contemporânea, Rio de Janeiro, 8, p. I8I-202.

BARNEY, J. B., Hesterly, W. (1996). Organizational Economics: understanding the relationship between Organizations and Economic Analysis in Handbook of Organizations, Rouledge, London.

BARUSCO FILHO, P. (2003). Plano de Investimento Petrobras. Workshop PROMINP, Brasil.

CARLSSON, B., Stankiewicz, R. (1995). On the nature, function and composition of technological systems. In: Carlsson, B. (Ed.), Technological Systems and Economic Performance: The Case of Factory Automation. Kluwer Academic Publishers, Boston, Dordrecht, London.

CARLSSON, B., Jacobsson, S. Holménb, M. Rickne, A. (2002). Innovation systems: analytical and methodological issues. Research Policy, 3I, 233-245.

CHUNG, S. (2002) Building a national innovation system through regional innovation systems. Technovation 22, 485491.

COOKE, P., Schienstock, G. (1995). Regional Innovation Systems - design for the future.

COOKE, P. (1996). Regional innovation systems: an evolutionary approach. In: Baraczyk, H., Cooke, P., 
Heidenriech, R. (Eds.), Regional Innovation Systems. London University Press, London.

COOKE, P., Uranga, M. G., Etsebarria, G. (1997). Regional Innovation Systems: Institutional and organizational dimensions, Research Policy 26, 475-49I.

COOKE , P., Morgan, K. (1998). The Associational Economy: Firms, Regions and Innovation. Oxford University Press, UK.

COOKE, P., Heidenreich, M., Braczyk, H. J. (2004). Regional Innovation Systems: The role of governance in a globalized world. 2nd Edition, Routledge, UK.

CORIAT, B., Weinstein, O. (2002). Organizations, firms and institutions in the generation of innovation. Research Policy 31, 273-290.

DAVID, P., Foray, D. (1995). Assessing and Expanding the Science and Technology Knowledge Base, Science, Technology Industry Review, 16, OECD, Paris.

DEBRESSON, C., Amesse, F. (1991). Networks of innovators: a review and introduction to the issue. Research Policy, 20, p. 363-379.

LIPPARINI, A, Sobrero, M. (1997). Coodinating multi-firm innovative processes: entrepreneur as catalyst in small-firm networks in The formation of inter-organizational networks, edited by Mark Ebers, Oxford, Oxford University Press.

EDQUIST, C., Hommen, L., Johnson, B., Lemola, T., Malerba, F., Reiss, T., Smith, K. (1998). The ISE Policy Statement - The Innovation Policy Implications of 'Innovation Systems and European Integration' (ISE) Research Project. Sweden.

EIC - Energy Industries Coucil/British Trade International, (2002). Selling to Brasil - a Practical Guide for British Oil \& Gás Sector Supply Companies. EIC, UK.

EISENHARDT, K. (1985). Control: organizational and economic approaches Management Science, 3 I (2).

EISENHARDT, K., Martin. J. (2000). Dynamic Capabilities: What are they? Strategic Management Journal. 21, II05IIII.
FREEMAN, C. (1987). Technology Policy and Economic Performance: Lessons from Japan. Pinter, London.

FREEMAN, C. (1995). The national innovation systems in historical perspective. Cambridge J. Econ. 19 (I).

FREEMAN, C. (2002). Continental, national and subnational innovation systems - complementarity and economic growth. Research Policy 31, I91-2II.

GEELS, F.W. (2004). From sectoral systems of innovation to socio-technical systems Insights about dynamics and change from sociology and institutional theory Research Policy, Vol. 33, p. 897-920

GIDDENS, A. (1985). The Constitution of society: Outline of the theory of structuration. 4. ed. Cambridge: Polity.

GREEN, K. et al. (1999). The construction of the technoeconomic: networks vs. Paradigms. Research Policy, 28, p. 777-792

IEA - International Energy Agency. World Energy Investment Outlook 2003. IEA, 2003.

KUMARESAN, N., Miyazaki, K. (1999). An integrated network approach to systems of innovation - the case of robotics in Japan. Research Policy, 28, p. 563-585.

KÜPPERS, G., Pyka, A. (2002). The Self-organization of Innovation Networks: introductory remarks in Innovation Networks: Theory and Practice Cheltenham, Edward Elgar Publishing.

KÜPPERS, G. (2002). Complexity, self-organization and innovation networks: a new theoretical approach in Innovation Networks: Theory and Practice Cheltenham, Edward Elgar Publishing.

LALL, S. (1992). Technological capabilities and industrialization. World Development, 20(2), I65-182.

LUNDVALLL, B.-Å. ed. (1992). National Systems of Innovation: Towards a Theory of Innovation and Interactive Learning. Pinter Publishers, London.

LUNDVALLL, B.-Å., Johnson, B., Andersen, E.S., Dalun, B, (2002). National systems of production, innovation and competence building. Research Policy 31, 213-231. 
MALERBA, F. (2002). Sectoral systems of innovation and production. Research Policy 31, 247-264.

MALERBA, F. (2003). Sectoral Systems and Innovation and Technology Policy. Revista Brasileira de Inovação 2(2), 329375.

MALERBA, F. (2004). Public Policy and the Development and Growth of Sectoral Systems of Innovation. Beijing Globelics Conference.

MARSHALL, A. (196I) Principles of Economics, Cambridge, Cambridge University Press.

MIKKELSEN, A., Jøsendal, K., Steineke, J. M., Rapmund, A. (2004). TIP Focus Group on Energy Innovation System. Country Report - Upstream Oil and Gas in Norway. OECD, http://www.oecd.org/dataoecd//2/II/ 31967805.pdf

MOULIER-BOUTANG, Y. (2003) "O território e as políticas de controle do trabalho no capitalismo cognitivo". In: Galvão, Alexander P. et al. Capitalismo cognitivo: trabalho, redes inovação Rio de Janeiro, DP\&A.

NELSON, R.R. ed. (1993). National Systems of Innovation. A Comparative Analysis. Oxford University Press, Oxford.

NIOSI, J. (2002). National systems of innovations are " $x-$ efficient" (and $x$-effective) Why some are slow learners. Research Policy, 3I, 29I-302.

NOOTEBOOM (2004). Inter-Firm Collaboration, Learning and Networks: An Integrated Approach, London, Routledge.

NORTH, D. C. (1990). Institutions, institutional change and economic performance, New York, Cambridge University Press.

OEA (200I). Normalización de Indicadores de Innovación Tecnológica en América Latina y el Caribe - Manual de Bogotá. Organización de Estados Americanos (OEA), Washington, USA.

OECD (2001). Inovative Clusters - Drivers of National Innovation Systems. Organization For Economic CoOperation and Development.OECD, Paris.
OECD (2002). Dinamising National Innovation Systems. OECD, Paris.

PORTER, M. (1980). Competitive Strategy. Free Press, New York.

PORTER, M. (1990). The Competitive Advantage of Nations, The Free Press, New York.

PORTER, M. (1998). Clusters and the New Economics of Competition. Harvard Business Review, pp. 77-90.

PELLEGRIN, I., Samuel, R. (2004). Caracterização do Arranjo Produtivo Local da Bacia de Campos e a Estruturação de uma Rede de Empresas - A Rede PETROBC. SEBRAE-RJ. Rio de Janeiro, Brasil.

POWELL, W. W., Smith-Doerr, L. (1994) Networks and economic life. In: The Handbook of Economic Sociology, ed. Neil J. Smelser, Richard Swedberg, Princeton, Princeton University Press.

POWELL, W. W., Koput, K. W., Doerr-Smith, L. (1996). Interorganizational collaboration and the Locus of Innovation: networks of learning in Biotechnology. Administrative Science Quarterly, 4I, p. I I6-145.

POWELL, W. W. (1998). Learning from collaboration: knowledge and networks in the Biotechnology and Pharmaceutical industries. California Management Review, 40(3).

ROTHWELL, R. (1996). Industrial innovation: success, strategy, trends. In: Dodgson, Mark and Rothwell, R. The handbook of industrial innovation, Cheltenham, Edward Elgar.

SCHMITZ, H. (1999). Collective efficiency and increasing returns Cambridge Journal of Economics. 23, p. 465-483.

TEIXEIRA, A. Carteira de Investimentos 2003 a 2007 Empresas de petróleo (exceto Petrobras). Workshop PROMINP, 2003.

WILLIAMSON, E. O. (1996). The mechanisms of governance. Oxford University Press. 